\title{
INTEGRATED CONFIGURATION OF FOLDING ROOF-BIPV AND ITS OPTIMATION AT OFFICE BUILDING IN SURABAYA
}

\author{
Susan*, I Gusti Ngurah Antaryama**, Totok Noerwasito ** \\ *) Lecturer, Department of Interior Architecture, Ciputra University, Indonesia \\ **) Lecturer, Department of Architecture, Faculty of Civil Engineering and \\ Planning, Institute of Technology Sepuluh Nopember, Indonesia \\ e-mail: susan@ciputra.ac.id
}

\begin{abstract}
BIPV (Building Integrated Photovoltaics) refers to the application of PV (photovoltaic) in which the system as well as having the function of producing electricity, also takes the role of building form and element. Empirical facts show that PV in BIPV system is integrated as add-on element only. They didn't take the role as form giver yet. Electricity output generized by BIPV depends on the amount of solar radiation received by $P V$ panel. There are some factors affect the amount of radiation received. Two of them are tilt and orientation angle of $P V$ panel, and total area prepared for $P V$ panel installment.This research try to rise electricity output by collaborating those two factors with orientation and multiplicity principle in folding concept. Folding element can be arranged based on optimum tilt and orientation angle to reach maximum radiation supply. Also, the collaboration results in bigger surface area to receive higher solar irradiance. Experiment with simulation as it tools will be used as research method to get the optimal configuration of Folding Roof-BIPV.
\end{abstract}

Keywords: annual radiation received, BIPV, folding roof, orientation, uniformity, tilt

\begin{abstract}
ABSTRAK
BIPV (Building Integrated Photovoltaics) mengacu pada penerapan PV (fotovoltaik) dimana sistemnya yang selain memiliki fungsi menghasilkan listrik, juga mengambil peran elemen dan bentuk bangunan. Fakta empiris menunjukkan bahwa PV dalam sistem BIPV diintegrasikan sebagai elemen tambahan saja. Mereka belum mengambil peran sebagai bentuk pemberi. Output listrik yang dihasilkan oleh BIPV tergantung pada jumlah radiasi matahari yang diterima oleh panel PV. Ada beberapa faktor mempengaruhi jumlah radiasi yang diterima. Dua diantaranya adalah kemiringan dan orientasi sudut panel PV, dan total area yang disiapkan untuk in-
\end{abstract}


stalasi panel PV. Penelitian ini mencoba untuk meningkatkan output listrik dengan mengkolaborasiakan dua faktor tersebut dengan orientasi dan prinsip keragaman dalam konsep lipat. Elemen lipat bisa diatur berdasarkan kemiringan optimal dan orientasi sudut untuk mencapai pasokan radiasi maksimum. Juga, hasil kolaborasi di daerah permukaan yang lebih besar untuk menerima radiasi matahari yang lebih tinggi. Percobaan dengan simulasi sebagai alat akan digunakan sebagai metode penelitian untuk mendapatkan konfigurasi optimal atap lipat-BIPV.

Kata Kunci: radiasi tahunan yang diterima, BIPV, atap lipat, orientasi, keseragaman, kemiringan

\section{INTRODUCTION}

Energy production commonly described as separated part from the built environment, with large scale power generation, and located some distance from the end user (Pitt, 2004). Energy generation (heat or electricity) by individual buildings or small groups of buildings at the small scale can be defined as microgeneration. One of promising microgeneration technologies is photovoltaic. One of its system called BIPV (Building Integrated Photovoltaic) gives more advantages such as reducing cost. The use of PV panels as building envelope will substitude the need of conventional building's material. BIPV refers to the application of PV in which the system, as well as having the function of producing electricity, also takes on the role of building form and elements. One of interesting solution from BIPV application is the use of huge vertical facade in mid and high-rise building at urban area.

The work of BIPV system as a potential renewable technology depends on the amount of radiation that reach PV cell, factors related to PV cell, and factors related to architecture itself. The last means that the architecture form will influence the efficiency of BIPV, and BIPV will influence the form of architecture. One of architectural approach to create architecture forms is folding design. Folding architecture has the essence of orientation and multiplicity. In folding architecture, orientation can be arranged based on design needs (Crosbie, 2004). Figure 1 shows the example of folding design. Meanwhile, in BIPV, the optimal orientation of PV panels take a big role in determining the output of electricity generation. Based on orientation principle in folding architecture as well as in BIPV, folding architecture can be used as form giver to BIPV. Determination of PV panels and folding orientation can be arranged to get the optimal radiation (Figure 2). In the orientation arrangement there is an essence of multiplicity, created by interval folding angle on the building envelope. Folding process and folding angle interval will create big area of building envelope. Big area of building envelope will add radiation receiving surface compared to architecture without folding.

Getting the optimum folding roof configuration is the aim of this research. Optimal folding roof is the roof that received the biggest annual radiation and also has the highest procentage of uniformity. There are 3 optimation standards that will be used in this research. First is the standard of electrical energy needed by an office, it is around $240 \mathrm{kWh} / \mathrm{m}^{2} /$ year (Marzuki and Rusma, 2012). Second is the target 
of Government National Energy Program, which wants to substitute the use of fossil fuel into renewable energy resources as much as 7\%. Third is optimation limitation for uniformity procentage. BIPV configuration should has at least $80 \%$ uniformity percentage of annual electrical energy produced (Mehleri, 2010).

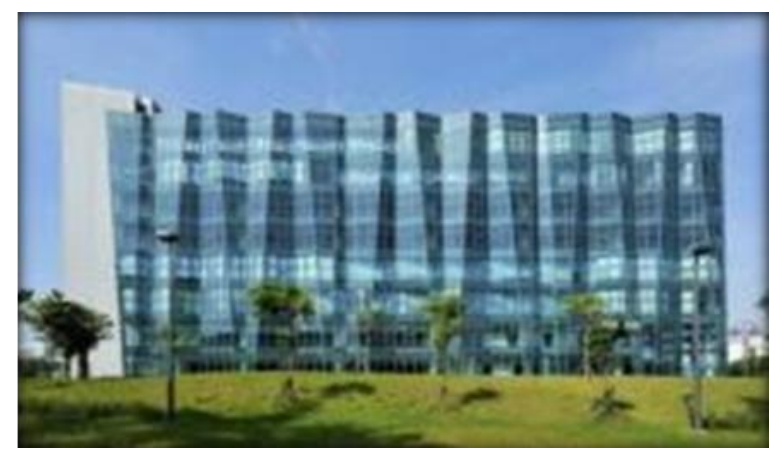

Figure 1. Folding Design at Neo Solar Power Office Source: Dailey, 2011

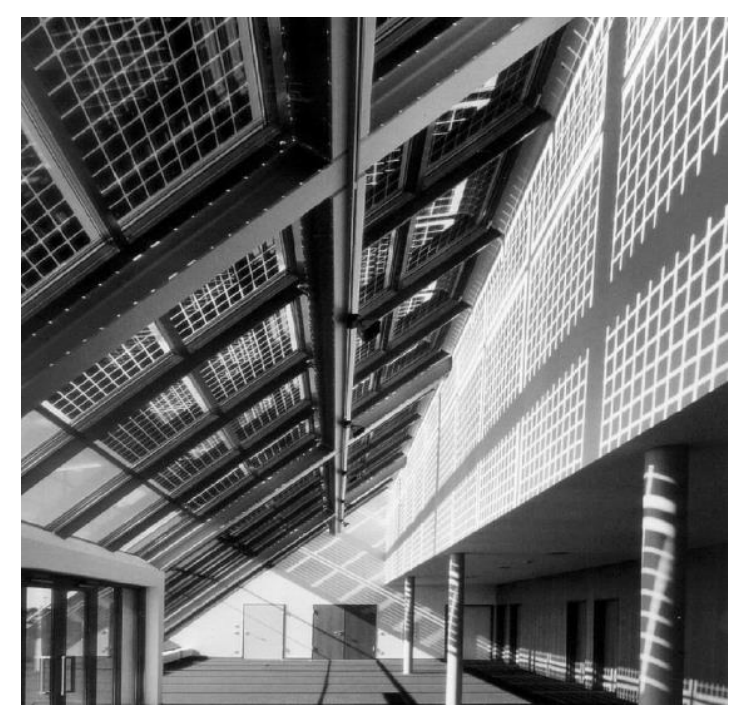

Figure 2. PV Panel Installation at Public Building with Optimum Tilt Angle and Fixed Orientation Source: Benemann, dkk, 2001

\section{THEORY / RESEARCH METHODS}

There are three groups of factors that influence the work of BIPV. There are external factor (solar irradiance), PV cell factors, and BIPV factors. Related to external factor, it is known that the sun moves from $23^{\circ}$ south latitude to $23^{\circ}$ north latitude and vice versa. Higher latitude area will get lower solar irradiance. Krishan (2001: 
108) said, for warm-humid area that placed near to the equator, sun moves mostly above the building, so the roof will get highest solar irradiance. This research took place in Surabaya, which is located in $7^{\circ} 14^{\prime} 24^{\prime \prime}$ south latitude. Surabaya receive high solar irradiance, and for any building located in Surabaya the highest solar irradiance will be received by their roof.

Beside solar irradiance as the external factor, there are some factors related to PV cell itself. First is the cell's temperature. Optimum temperature for PV cells to generate electricity is at $25^{\circ} \mathrm{C}$. An air gap can be used to prevent the rising of PV cell's temperature (Yun, et al, 2006). Second is PV cells number in a modul. This will directly influence the electricity voltage generated by PV cells. Commonly, the standard modul range between 36 until 216 cells. For 36 cells panel, the modul size is $1184 \mathrm{~mm} \times 545 \mathrm{~mm} \times 35 \mathrm{~mm}$. Third are silicon type and PV cell's color. PV cell is made from semiconductor material, silicon ( $\mathrm{Si}$ ). Monocrystalline Silicon has the highest efficiency. Usually, PV cell has dark color in order to minimize light reflection and maximize the electricity generation. Fourth is PV modul efficiency characteristic. Each brand has its own efficiency characteristic. This research use $80 \mathrm{Wp}$ PV cell made by "Bell" which has $12,38 \%$ efficiency characteristic (Figure 3).

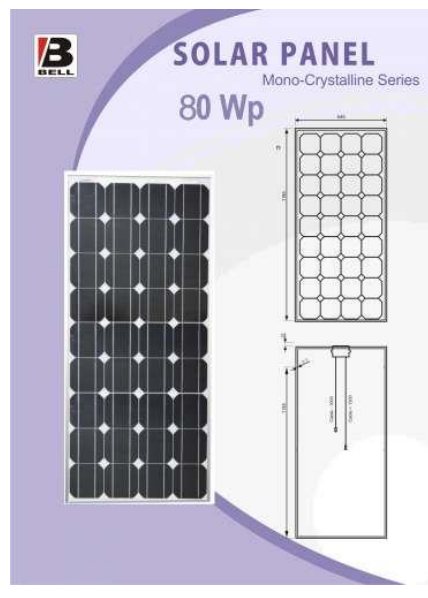

Figure 3. Modul of 36 Cells PV Panel by Bell Source: Bell, 2012

At BIPV system, PV cells commonly placed as building envelope and become an integrated part of the building. As an integrated part of the building, the building's form will influence the efficiency of BIPV. Surface to volume ratio will be an indicator wheteher the building will minimize or maximize radiation received. At BIPV case, solar radiation want to be received as much as possible. Brown (1990) explained that with the same volume, radiation received by a long shape buildings will be higher than that by compact buildings. Markus \& Morris (1980) give 2:2:16 building proportion as a good surface to volume ratio in receiving solar's radiation. Sometimes because of building's form, radiation received can't be 
maximized. Losing energy for about $10 \%$ is assumed as good compromize between shape and BIPV function (Urbanetz, et al, 2011). Another factor related to BIPV efficency is shading. Self shading and environment shading will reduce the electricity output. Environment shading will reduce power output from BIPV up to 40\%-60\% from its maximum ability (Urbanetz, et al, 2011). Meanwhile for selfshading, Ubisse, et al (2009) explained that using 6 dioda in one single panel will minimize the effect of self shading. Optimal proportion between transparant materials and opaque PV moduls to total facade area is another factor that should be concerned when analyzing BIPV efficiency. In area with strong radiation, the optimal proportion range between $30 \%-40 \%$ (Yun, 2006).

Combination of tilt angle and orientation angle will definetely influenced BIPV system, both as architectural form giver and electricity generation. In this paper, the combination of tilt angle and orientation angle will create folding-BIPV configurations. As general rules, optimal tilt angle is equal to latitude angle. But for area with low latitude, low tilt angle won't be too effective since there will be dust covering PV surface. Research done by Hussein, et al (2003) found that for area with low latitude, optimum tilt angle range between $20^{\circ}-30^{\circ}$ and optimum orientation angle range between $-15^{\circ}$ to $15^{\circ}$ facing equator (Figure 4 ).

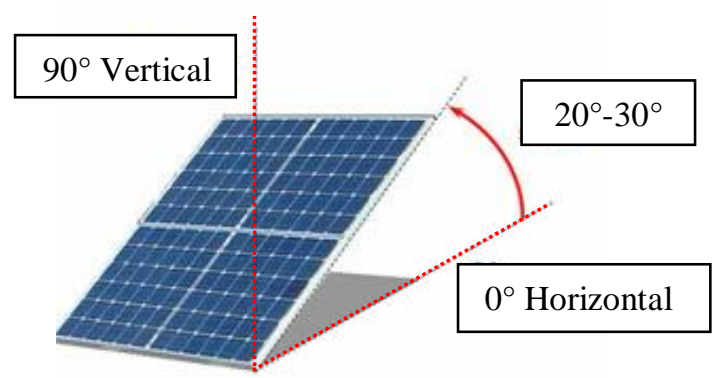

Figure 4. Illustration of Tilt Angle for PV Panel Source: www.bipv.ch/, 2012

\section{Research Methods}

Experimental method is used to know the relationship between tilt and orientation setting to annual radiation received by folding roof. Other influencing factors that affect the work of BIPV will be isolated. Simulation is used as a tool of experimental method to calculate annual radiation received $\left(\mathrm{kWh} / \mathrm{m}^{2}\right)$ by selected configurations. Gradient diagram is used for choosing the optimum configuration.

\section{RESULTS AND DISCUSSION}

\section{Experiment}

Pretest, treatment, and posttest condition are shown in the Table 1. 
Table 1. Experiment Method

\begin{tabular}{ccc}
\hline Pretest & Treatment & Posttest \\
\hline $\begin{array}{c}\text { Configuration of solar } \\
\text { radiation heat gain } \\
\text { building. }\end{array}$ & $\begin{array}{c}\text { Configuration of folding roof } \\
\text { with } 10^{\circ}-15^{\circ} \text { interval based on } \\
\text { solar's altitude angle. }\end{array}$ & $\begin{array}{c}\text { Variation of folding roof } \\
\text { configuration. }\end{array}$ \\
\hline
\end{tabular}

\section{Models}

Base case model for pretest condition is arranged based on these theories:

1. Tipology of building for solar radiation heat gain with 2:2:16 proportion (Markus \& Morris, 1980)

2. Floor to floor height for office building is about $4 \mathrm{~m}-4.2 \mathrm{~m}$ (Kohn and Katz, 2002)

Based on theories above, base case model dimentions are:

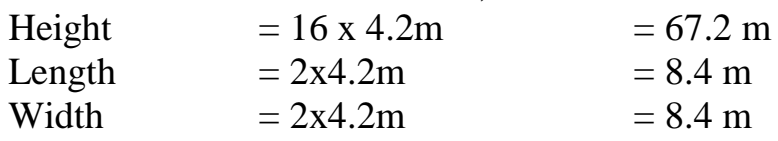

The needs of $\mathrm{AC}$ and artificial lighting are general rules in designing office building. In relation to $\mathrm{AC}$ installment, compact building shape will increase its efficiency (Givoni, 1998)

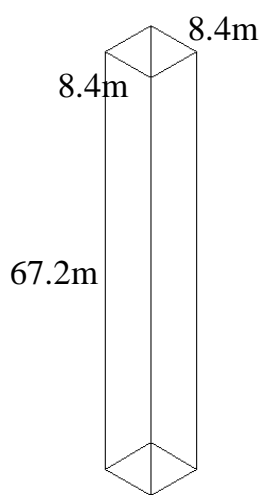

Figure 5. Base Case Model

Table 2. PV Placement on Base Case Model

\begin{tabular}{|c|c|c|c|c|}
\hline & Model & $\begin{array}{c}\text { The Number } \\
\text { of Solar Panel }\end{array}$ & $\begin{array}{c}\text { Area/panel } \\
\left(\mathbf{m}^{2}\right)\end{array}$ & $\begin{array}{c}\text { Total Area } \\
\left(\mathbf{m}^{2}\right)\end{array}$ \\
\hline \multirow{4}{*}{ Roof } & & 105 & 0,64528 & 67,7565 \\
\hline & & & & \\
\hline & & & & \\
\hline & & & & \\
\hline
\end{tabular}


Folding models for roof with various possibilities of tilt and orientation angles are arranged based on these theories:

1. Base case model as shown in Figure 5 and Table 2.

2. Various possibilities of optimum tilt and orientation angles based on solar's azimuth and solar's altitude.

3. Folding roof configurations based on solar's altitude and $10^{\circ}-15^{\circ}$ interval (Hussein, et al, 2004) placed between $10^{\circ}-75^{\circ}$ (for North orientation), $3^{\circ}-71^{\circ}$ (for South orientation), $3^{\circ}-75^{\circ}$ (for East orientation), $10^{\circ}-78^{\circ}$ (for West orientation).

4. 36 cells opaque monocrystalline PV panel modul (size: $1184 \mathrm{~mm}$ x $545 \mathrm{~mm}$ x 35 $\mathrm{mm})$.

5. Placement of PV panel on both sides of folding shape to maximize the uniformity of annual radiation received.

Totally, there are 27 models for folding roof based on solar's altitude. The number of the models are then filtered by two parameters. They are:

1. Optimal tilt angle $\left(20^{\circ}-30^{\circ}\right)$

2. Maximum surface area (bigger than surface area of base case and bigger than surface area of optimal angle configuration)

Some of folding models are shown in Table 3.

Table 3. Various possibilities of Folding Roof

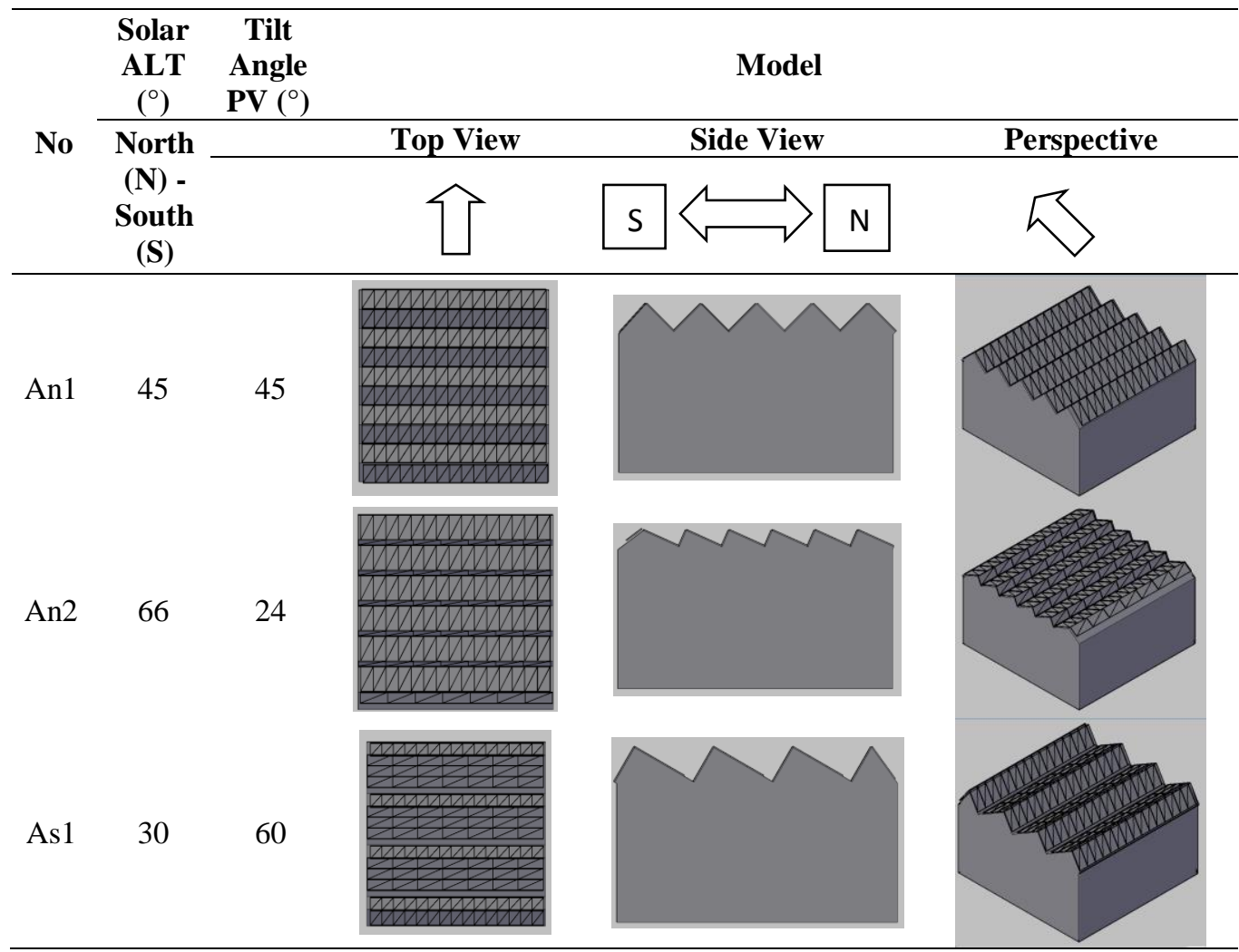


Table 3. Continue

\begin{tabular}{|c|c|c|c|c|c|}
\hline \multirow{3}{*}{ No } & $\begin{array}{l}\text { Solar } \\
\text { ALT } \\
\left({ }^{\circ}\right) \\
\end{array}$ & $\begin{array}{c}\text { Tilt } \\
\text { Angle } \\
\text { PV }\left(^{\circ}\right) \\
\end{array}$ & \multicolumn{3}{|c|}{ Model } \\
\hline & North & & Top View & Side View & Perspective \\
\hline & $\begin{array}{l}\text { South } \\
\text { (S) }\end{array}$ & & & & \\
\hline As2 & 45 & 45 & 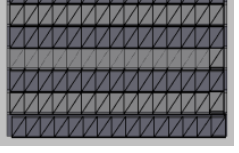 & & \\
\hline & $\begin{array}{c}\text { East (E) } \\
\text {-West } \\
(W)\end{array}$ & & & $\lambda$ & \\
\hline Ae1 & 41 & 49 & & & \\
\hline Ae2 & 65 & 25 & & & \\
\hline Aw1 & 44 & 46 & & & \\
\hline Aw2 & 65 & 25 & & & \\
\hline
\end{tabular}

Annual Radiation Received: Calculation and Analyses

These models are then simulated using Archipak 5.1 software. This software has the ability to calculate the amount of annual radiation received on average day of 12 months, on a sloping surface. This paper presents calculation using climate data of Surabaya from 2008-2012. 
Table 4. Calculation for Total Annual Radiation Received

a. Base Case

\begin{tabular}{|c|c|c|c|c|c|c|c|c|c|}
\hline \multirow[b]{2}{*}{$\begin{array}{l}\mathrm{Na} \\
\mathrm{me}\end{array}$} & \multirow[b]{2}{*}{$\begin{array}{c}\text { Orient } \\
\text { ation }\end{array}$} & \multirow[b]{2}{*}{ Tilt } & \multicolumn{3}{|c|}{$\begin{array}{c}\text { Side } 1 \text { Annual Radiation } \\
\text { Received }\end{array}$} & \multicolumn{3}{|c|}{$\begin{array}{c}\text { Side } 2 \text { Annual Radiation } \\
\text { Received }\end{array}$} & \multirow{2}{*}{$\begin{array}{c}\text { Total } \\
\text { Annual } \\
\text { Radiation } \\
\text { Received } \\
(\mathbf{k W h})\end{array}$} \\
\hline & & & $\begin{array}{l}\text { Area } \\
\left(\mathbf{m}^{2}\right)\end{array}$ & $\begin{array}{c}\text { Annual } \\
\text { Radiation } \\
\text { Received } \\
\left(\mathbf{k W h} / \mathbf{m}^{2}\right)\end{array}$ & $\begin{array}{c}\text { Annual } \\
\text { Radiation } \\
\text { Received } \\
(\mathbf{k W h})\end{array}$ & $\begin{array}{r}\text { Area } \\
\left(\mathbf{m}^{2}\right) \\
\end{array}$ & $\begin{array}{c}\text { Annual } \\
\text { Radiation } \\
\text { Received } \\
\left(\mathbf{k W h} / \mathbf{m}^{2}\right)\end{array}$ & $\begin{array}{c}\text { Annual } \\
\text { Radiation } \\
\text { Received } \\
(\mathbf{k W h})\end{array}$ & \\
\hline $\mathrm{a}$ & $\mathrm{b}$ & $\mathrm{c}$ & $\mathrm{d}$ & $\mathrm{e}$ & $f(d x e)$ & $\mathrm{g}$ & $\mathrm{h}$ & $\mathrm{i}(\mathrm{gxh})$ & $j(f+i)$ \\
\hline $\begin{array}{l}\text { Flat } \\
\text { roof }\end{array}$ & 0 & 0 & 67,76 & 2294 & $155.441,44$ & - & - & - & $155.441,44$ \\
\hline \multicolumn{9}{|c|}{ b. North (N)-South (S) Folding Roof Configuration } & \\
\hline \multirow[b]{2}{*}{$\begin{array}{l}\text { Na } \\
\text { me }\end{array}$} & \multirow{2}{*}{$\begin{array}{c}\text { Orient } \\
\text { ation }\end{array}$} & \multirow[b]{2}{*}{ Tilt } & \multicolumn{3}{|c|}{$\begin{array}{l}\text { North Side Annual } \\
\text { Radiation Received }\end{array}$} & \multicolumn{3}{|c|}{$\begin{array}{l}\text { South Side Annual } \\
\text { Radiation Received }\end{array}$} & \multirow{2}{*}{$\begin{array}{c}\text { Total } \\
\text { Annual } \\
\text { Radiation } \\
\text { Received } \\
\text { (kWh) } \\
\end{array}$} \\
\hline & & & $\begin{array}{l}\text { Area } \\
\left(\mathbf{m}^{2}\right)\end{array}$ & $\begin{array}{c}\text { Annual } \\
\text { Radiation } \\
\text { Received } \\
\left(\mathbf{k W h} / \mathbf{m}^{2}\right)\end{array}$ & $\begin{array}{c}\text { Annual } \\
\text { Radiation } \\
\text { Received } \\
(\mathbf{k W h}) \\
\end{array}$ & $\begin{array}{r}\text { Area } \\
\left(\mathbf{m}^{2}\right) \\
\end{array}$ & $\begin{array}{c}\text { Annual } \\
\text { Radiation } \\
\text { Received } \\
\left(\mathbf{k W h} / \mathbf{m}^{2}\right)\end{array}$ & $\begin{array}{c}\text { Annual } \\
\text { Radiation } \\
\text { Received } \\
(\mathbf{k W h})\end{array}$ & \\
\hline $\mathrm{a}$ & $\mathrm{b}$ & $\mathrm{c}$ & $\mathrm{d}$ & $\mathrm{e}$ & $\mathrm{f}(\mathrm{dxe})$ & $\mathrm{g}$ & $\mathrm{h}$ & $\mathrm{i}(\mathrm{gxh})$ & $\mathrm{j}(\mathrm{f}+\mathrm{i})$ \\
\hline An1 & $\begin{array}{l}\text { North- } \\
\text { South }\end{array}$ & 45 & 48,4 & 2091 & $1.204,40$ & 48,4 & 1761 & $85.232,40$ & $186.436,80$ \\
\hline An2 & $\begin{array}{l}\text { North- } \\
\text { South }\end{array}$ & 24 & 58,08 & 2301 & $133.642,08$ & 27,1 & 1935 & $52.438,50$ & $184.080,58$ \\
\hline As 1 & $\begin{array}{l}\text { North- } \\
\text { South }\end{array}$ & 60 & 50,33 & 2255 & $113.426,50$ & 38,72 & 1803 & $69.776,10$ & $183.202,60$ \\
\hline As2 & $\begin{array}{l}\text { North- } \\
\text { South }\end{array}$ & 45 & 48,4 & 2091 & $101.204,40$ & 48,4 & 1761 & $85.232,40$ & $186.436,80$ \\
\hline
\end{tabular}

c. East (E)-West (W) Folding Roof Configuration

\begin{tabular}{|c|c|c|c|c|c|c|c|c|c|}
\hline \multirow[b]{2}{*}{$\begin{array}{l}\mathrm{Na} \\
\mathrm{me}\end{array}$} & \multirow[b]{2}{*}{$\begin{array}{c}\text { Orient } \\
\text { ation }\end{array}$} & \multirow[b]{2}{*}{ Tilt } & \multicolumn{3}{|c|}{$\begin{array}{c}\text { East Side Annual } \\
\text { Radiation Received }\end{array}$} & \multicolumn{3}{|c|}{$\begin{array}{l}\text { West Side Annual } \\
\text { Radiation Received }\end{array}$} & \multirow[b]{2}{*}{$\begin{array}{c}\text { Total } \\
\text { Annual } \\
\text { Radiation } \\
\text { Received } \\
(\mathbf{k W h}) \\
\end{array}$} \\
\hline & & & $\begin{array}{l}\text { Area } \\
\left(\mathbf{m}^{2}\right)\end{array}$ & $\begin{array}{c}\text { Annual } \\
\text { Radiation } \\
\text { Received } \\
\left(\mathbf{k W h} / \mathbf{m}^{2}\right)\end{array}$ & $\begin{array}{c}\text { Annual } \\
\text { Radiation } \\
\text { Received } \\
(\mathbf{k W h})\end{array}$ & $\begin{array}{l}\text { Area } \\
\left(\mathbf{m}^{2}\right)\end{array}$ & $\begin{array}{c}\text { Annual } \\
\text { Radiation } \\
\text { Received } \\
\left(\mathbf{k W h} / \mathbf{m}^{2}\right)\end{array}$ & $\begin{array}{c}\text { Annual } \\
\text { Radiation } \\
\text { Received } \\
(\mathbf{k W h})\end{array}$ & \\
\hline $\mathrm{a}$ & $\mathrm{b}$ & $\mathrm{c}$ & d & $\mathrm{e}$ & $f(d x e)$ & $\mathrm{g}$ & $\mathrm{h}$ & $\mathrm{i}(\mathrm{gxh})$ & $j(f+i)$ \\
\hline Ae1 & $\begin{array}{l}\text { East- } \\
\text { West } \\
\end{array}$ & 49 & 48,4 & 2367 & $114.562,80$ & 43,23 & 2300 & $99.360,00$ & $213.922,80$ \\
\hline $\mathrm{Ae} 2$ & $\begin{array}{l}\text { East- } \\
\text { West }\end{array}$ & 25 & 58,08 & 2307 & $134.036,70$ & 27,1 & 2351 & $63.712,10$ & $197.748,80$ \\
\hline Aw1 & $\begin{array}{l}\text { East- } \\
\text { West }\end{array}$ & 46 & 48,4 & 2357 & $114.078,80$ & 48,4 & 2385 & $115.434,00$ & $229.512,80$ \\
\hline Aw2 & $\begin{array}{l}\text { East- } \\
\text { West }\end{array}$ & 25 & 27,1 & 2347 & $63.603,70$ & 58,08 & 2314 & $134.443,40$ & $198.047,10$ \\
\hline
\end{tabular}


As shown in Table 4, maximum surface area configurations in each orientation has bigger surface area compared to flat roof and optimal angle configurations. Compared to flat roof, the differences is about 35,23\%-42,84\%, and compared to optimal angle configurations the differences is about 7,57\%-13,63\%. The procentage of PV to the total surface folding area in maximum surface configurations is $14,41 \%$. As the surface area are getting larger, the annual radiation received for maximum area configurations in each orientation (as shown in Table 5) also getting higher. As shown in Figure 6, compared to flat roof, total annual radiation received by maximum surface configuration are $19,94 \%$ to $47,65 \%$ higher, while optimum angle configuration only $17,86 \%-27,41 \%$ higher.

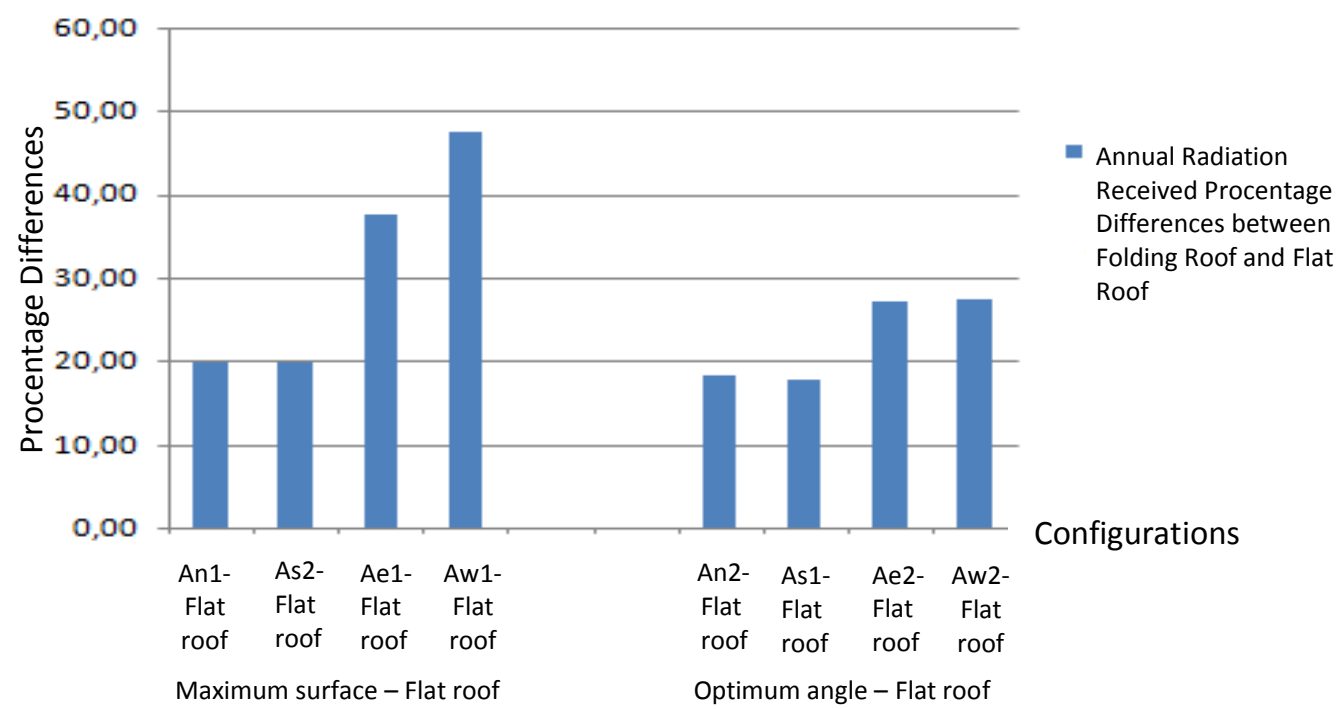

Figure 6. Annual Radiation Received Procentage Differences between Folding Roof and Flat Roof

Biggest radiation is received by Aw1 configuration. It is a folding roof configuration which has folding facing into East and West orientation. It can be explained through some theories. First, in equator the sun moves mostly on the top of the building (Krishan dkk, 2001). Second, installment of PV facing East and West orientation based on the asumption that East side will receive radiation for half day until 12 o'clock in the afternoon and the West side will receive radiation for half day until 6 o'clock in the evening (Bonifacius, 2012). Also, the result of Archipak simulation shows that annual radiation received $\left(\mathrm{kWh} / \mathrm{m}^{2}\right)$ for East-West folding roof is higher than that for North-South orientation.

Uniformity procentage for each configuration can be seen in Figure 7. It can be seen that maximum surface configurations has the higher uniformity procentage compared to optimal angle configurations. Aw1 configuration has highest uniformity. Since east and west sun radiation is equal, so if the receiving surface has the same size, the uniformity will be higher. This is the reason why Aw1 has the highest uniformity. 


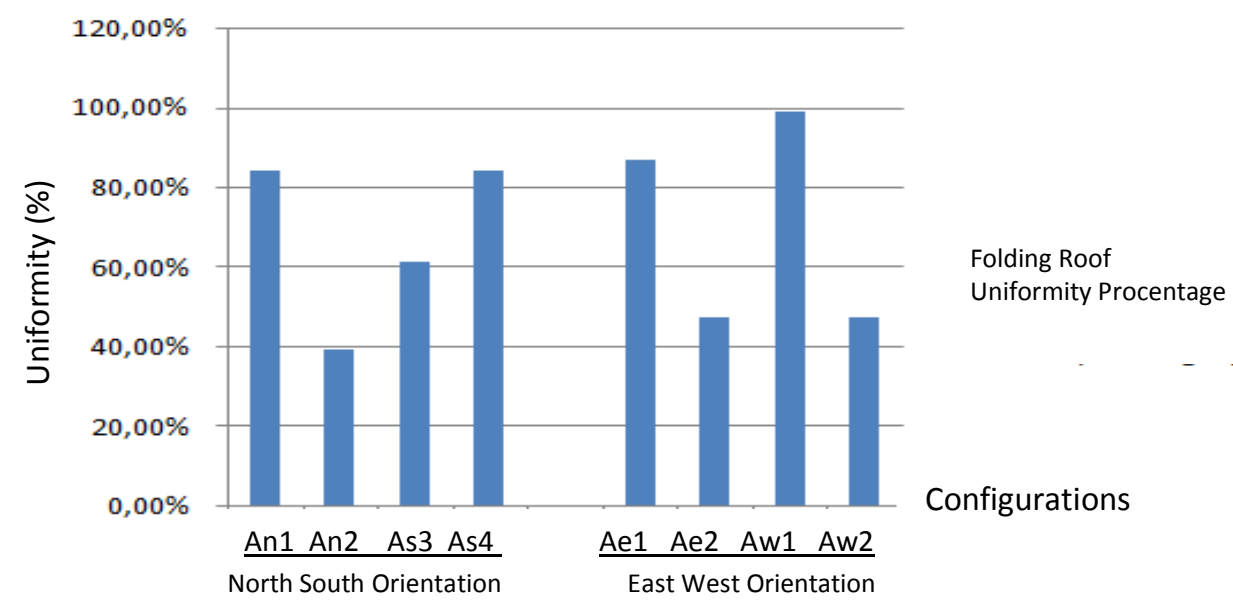

Figure 7. Uniformity Procentage of Each Folding Roof Configuration

For optimation analysis, annual radiation received are converted into electricity energy. The results, together with the uniformity procentage are then plotted into Gradient Diagram, as shown in Figure 8. Electricity energy created by Aw1 configuration can supply $10,5 \%$ of total electricity energy needed. This already exceed the fossil fuel substitution target limit (7\%). Related to uniformity procentage, all maximum surface configurations are exceed optimum uniformity limit. So, the optimum folding roof configuration in this research is Aw1 (tilt $\left.=46^{\circ}\right)$.

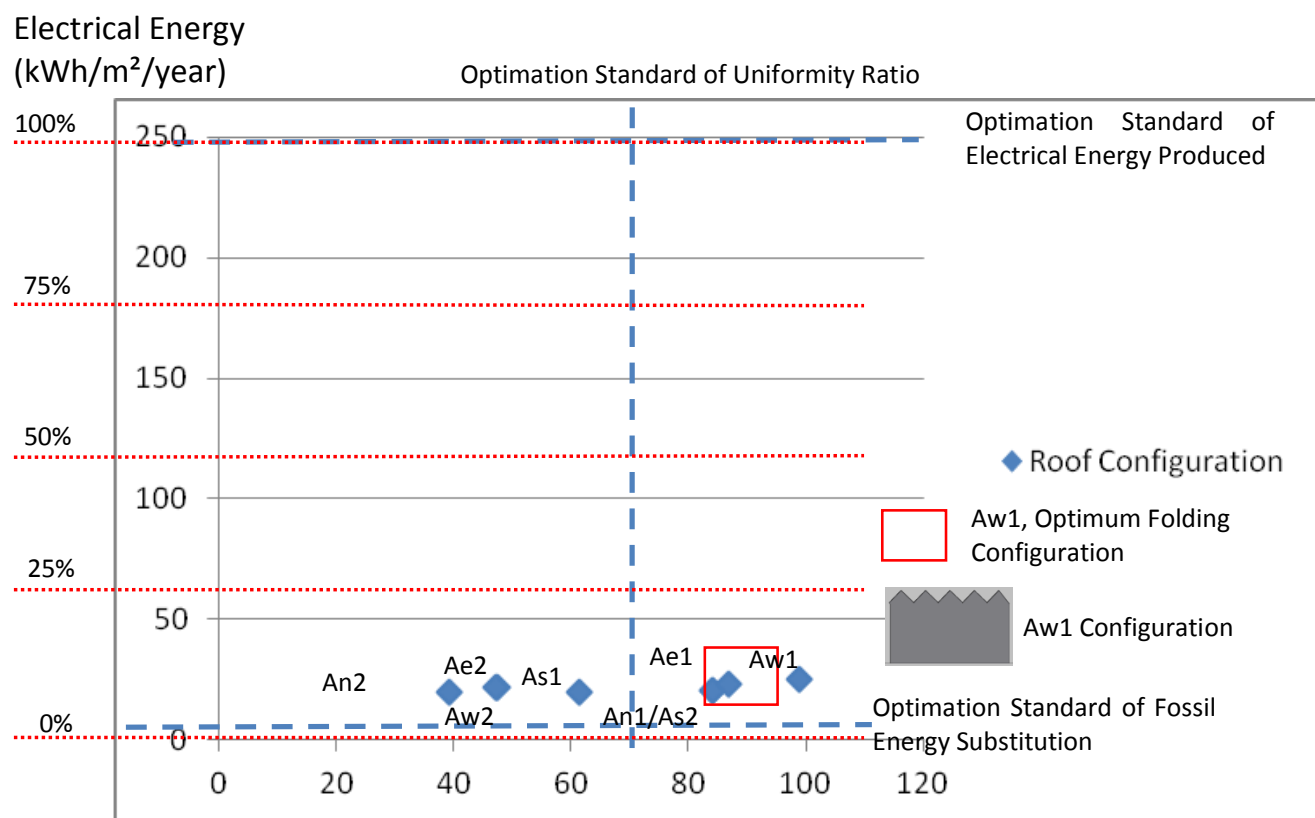

Uniformity (\%)

Figure 8. Gradient Diagram for Folding Roof Optimation 


\section{CONCLUSIONS}

The research are done by experimental methods in order to get the optimal configuration of Folding Roof-BIPV. In terms of LCB building, the calculation shows that electricity energy produced by folding roof-BIPV are bigger than the one produced by flat roof-BIPV.

East-West orientation, with $45^{\circ}$ tilt angle is the most optimum configuration since it has the abilities to receive highest daily solar radiation all over the year. Furthermore, east-west orientation has highest uniformity of annual radiation received. This conclusion are match with the theory shown by Krishan (2001), Bonifacius (2012), Koenigsberger (1973) and Brown (1990).

Electrical energy produced by folding roof-BIPV, on east-west orientation, with $45^{\circ}$ tilt angle, could produce $25.17 \mathrm{kWh} / \mathrm{m}^{2} /$ year. This number can substitute $10.5 \%$ electrical energy needed from fossil fuel, passing the Government National Energy Mix Program target.

\section{REFERENCES}

Benemann, J., Chehab, O., Schaar-Gabriel, E. (2001), Building-integrated PV modules, PILKINGTON Solar International GmbH, Muehlengasse 7, D50667 Cologne, Germany, pp. 351.

Bell (2012), http://www.powerbell.indonetwork.co.id, (Accessed on 17 April 2012). Bonifacius, N. (2012), Optimalisasi Kondisi Termal dan Pembangkitan Energi pada Atap Photovoltaic Terintegrasi di Daerah Tropis Lembab, Insititut Teknologi Sepuluh Nopember, Surabaya.

Brown, G. Z. (1990), Matahari, Angin, dan Cahaya: Strategi Perancangan Arsitektur, Bandung.

Crosbie, M. J. (2004), Architecture for Science, The Images Publishing Group Pty Ltd, Australia.

Dailey, J. (2011), <http://www. http://inhabitat.com/neo-solar-power-headquartershas-a-striking-blue-folded-facade/> (Accessed on November, 29th, 2011).

DeChiara, J., Panero, J., Zelnik, M., (2001), Time Saver Standard for Interior Design and Space Planning, McGrawHill.

Yun, G. Y., McEvoy, M., Steemers, K. (2006), Design and Overall Energy Performance of A Ventilated Photovoltaic Facade, The Martin Centre for Architectural and Urban Studies, Department of Architecture, University of Cambridge, UK, pp. 383-394.

Givoni, B. (1998), Climate Considerations in Building and Urban Design, Van Nostrand Reinhold.

Hussein, H. M. S., Ahmad, G. E., El-Gethany, H. H. (2004), Performance Evaluation of Photovoltaic Modules at Different Tilt Angles and Orientations, Department of Solar Energy, National Research Center, El-Tahrir Street, Dokki, Cairo, Egypt, pp. 2441-2452.

Kohn, A. E. and Katz, P. (2002), Building Type Basics for Office Building, John Wiley \& Sons, New York. 
Krishan, A., Baker, N., Yannas, S., Szokolay, S.V. (2001), Climate Responsive Architecture, A Design Handbook for Energy Efficient Buildings, McGrawHill, New Delhi.

Lechner, N. (2009), Heating, Cooling, Lighting: Sustainable Design Methods for Architects, John Wiley \& Sons, USA.

Markus, T. A. and Morris, E. N (1980), Buildings, Climate and Energy, Pitman.

Martin, N. and Ruiz, J. M, (2000), Calculation of The PV Modules Angular Losses under Field Conditions by Means of An Analytical Model, UPM-Instituto de Energia Solar, Madrid, Spain.

Marzuki, A. and Rusma (2012), Audit Energi pada Bangunan Gedung Direksi PT. Perkebunan Nusantara XIII, Jurusan Teknik Elektro Politkenik Negeri Pontianak, Pontianak.

Mehleri, E. D, Zervas, P. L, Sarimveis, H., Palyvos, J. A, Markatos, N. C, (2010), Determination of The Optimal Tilt Angle and Orientation for Solar Photovoltaic Arrays, National Technical University of Athens, School of Chemical Engineering, Athens, Greece

Pitt, A. (2004), Planning and Design Strategies for Sustainibility and Profit, Architectural Press, Britain.

Swiss BiPV Competence Centre (2012), Orientation: Angle of Inclination, $<$ http://www.bipv.ch/> (Accessed on 12 February 2012).

Urbanetz, J., Zomer, C., Ruther, R. (2011), Compromises between Form and Function in Grid-Connected, Building-Integrated Photovoltaics (BIPV) at Low-latitudes Sites, a Universidade Federal de Santa Catarinal UFSC, Campus Universitário Trindade, Brazil, pp. 2107-2113.

Ubisse, A. and Sebitosi, A. (2009), A New Topology to Mitigate The Effect of Shading for Small Photovoltaic Installations in Rural Sub-Saharan Africa, University of Cape Town, Cape Town, South Africa, pp.17. 
This page intentionally left blank 